\title{
Getrouwheid en rechtmatigheid
}

\author{
Prof. J.H. Blokdijk
}

\section{Inleiding}

In het nummer van januari/februari 1993 van dit blad heeft J. ten Wolde een beschouwing over de jaarrekeningcontrole gegeven, walarin hij onder meer stelt dat rechtmatigheid een element zou zijn van getrouwheid. Kort daarop, in juli 1993, heeft het NIVRA een herziening van ontwerp-Richtlijn voor de Accountantscontrole 3.01, getiteld "Afbakening en inhoud van het onderzoek naar de getrouwheid van een verantwoording", het licht doen zien, waarin de opvatting van Ten Wolde lijkt te zijn overgenomen. Bij de algemene herziening van de (ontwerp-)Richtlijnen voor de Accountantscontrole (RAC) in 1996, die in wezen bestaat uit een vertaling van de International Standards on Auditing van de IFAC, is in een uitsluitend voor Nederland geldende paragraaf aan deze opvatting vastgehouden (RAC $\$ 200.7 \mathrm{~A}$ ).

Deze gedachte lijkt dus in Nederland algemeen aanvaard te zijn, maar niet daarbuiten. Dat noopt op zijn minst tot een nadere beschouwing van rechtmatigheid.

\section{Wat is rechtmatigheid?}

Ten Wolde vertaalt deze vraag als volgt: " $Z i j n$ bij de uitvoering van de hedriffsactiviteiten de relevante voorschriften in aanmerking genomen?" Hij constateert dat bij ondernemingen de

Prof. J.H. Blokdijk is directeur van J.H. Blokdijk Advies B.V. en adviseur van accountants en advocaten. Daarnaast is hij hoogleraar Toegepaste Accountantscontrole aan de Vrije Universiteit Amsterdam. Hij heeft vele vaktechnische functies bij het Koninklijk NIVRA vervuld en is lid van het bestuur van de Stichting Toezicht Effectenverkeer. controle op de naleving van voorschriften slechts relevant is voorzover deze van invloed zijn op 'het beeld van vermogen en resultaat'. Als een accountant een overtreding van andere voorschriften constateert, zal hij deze uiteraard melden aan de directie of, indien belangrijk, aan het toezichthoudend orgaan. Voor overheidsinstellingen wijst Ten Wolde op de expliciete verplichting van overheidsaccountants de naleving van de voorschriften ten aanzien van uitgaven en inkomsten te controleren; de eis dat de uitvoering dient te geschieden volgens de aanwijzingen van regering en parlement wordt aangeduid als: de rechtmatigheidseis. Ten Wolde acht het, met een verwijzing naar milieuvoorschriften en de Wet Ketenaansprakelijkheid, wenselijk ook in de openbare accountancy deze eis bij de controle afzonderlijk te onderscheiden en, zo blijkt uit de opbouw van zijn artikel, als element van de getrouwheid van verantwoordingen te beschouwen.

De eerdergenoemde ontwerp-Richtlijn 3.01 van het NIVRA lijkt hem hierin te volgen. In de aanhef van hoofdstuk 4 wordt de rechtmatigheid expliciet als een aspect van de getrouwheid van een verantwoording genoemd. Vervolgens zegt \$ 4.4: "Rechtmatigheid is een aspect dat duidt op de mate waarin het door het bestuur van een huishouding gevoerde financiële beleid (inclusief het financiële beheer), dat tot uitdrukking komt in de verantwoording, in overeenstemming is met de bestaande normering enlof regelgeving. Deze normering zal veelal vastliggen in statuten of, voor de overheid en non-profithuishoudingen, in specifieke wetten of begrotingen. De mate waarin rechtmatigheid een getrouwheidsaspect is, verschilt daarom van huishouding tot huishouding." Deze tekst is letterlijk overgenomen in 
RAC $\$ 200.7 \mathrm{~A}$, waarin rechtmatigheid wordt aangemerkt als element van getrouwheid. naast aanvaardbaarheid, toereikendheid en betrouwbaarheid.

Toch is het niet verwonderlijk dat de IFAC rechtmatigheid niet als een element van getrouwheid ziet. Immers, rechtmatigheid heeft betrekking op het handelen. hetgeen zowel doen als nalaten omvat; aanvaardbaarheid, toereikendheid en betrouwbaarheid betreffen de weergave van het handelen in een verantwoording. Rechtmatigheid lijkt dus een vreemde eend in de bijt van de getrouwheid. Als men art. 13 GBR leest, kan men niet anders concluderen dan dat 'getrouwheid van de verantwoording' betekent: dat de verantwoording 'aan de eraan te stellen eisen voldoet'.

In dit kader ontwaar ik voorts een nuanceverschil tussen Ten Wolde en het NIVRA. Voor de analyse is het zinnig onderscheid te maken tussen twee niveaus van rechtmatigheid:

- rechtmatigheid op totaalniveau: is het totaal van met name uitgaven binnen het geautoriseerde niveau gebleven?

- rechtmatigheid op detailniveau: zijn de afzonderlijke uitgaven en ontvangsten geschied volgens de regelen van het toepasselijke recht?

Ten Wolde sluit, door de verwijzing naar milieuvoorschriften en de Wet Ketenaansprakelijkheid, het detailniveau kennelijk volledig in. Behalve bij overheids- en non-profithuishoudingen lijkt het NIVRA zich, door de verwijzing naar voorschriften in statuten, voorshands te beperken tot rechtmatigheid op totaalniveau: het lijkt de rechtmatigheid nog niet uit te strekken tot detailniveau, tot de naleving van milieuvoorschriften en dergelijke. Maar dat kon wel eens een kwestie van tijd zijn, of van onduidelijkheid in de tekst: onder accountants is het al lang gemeengoed dat bij de controle de naleving van belastingwetten, milieuvoorschriften en dergelijke een rol moet spelen. Maar welke? Deze vraag is met vorengenoemde publicaties opnieuw aan de orde gesteld. Ten Wolde doet dit het meest duidelijk ten aanzien van overheidsinstellingen.

\section{De rol van rechtmatigheid bij overheidsinstellingen}

Overheidsaccountants dienen, althans bij het onderzoek van departementale jaarrekeningen, vast te stellen of ontvangsten en uitgaven rechtmatig zijn geschied, en daar dan ook over te rapporteren. In een artikel in het nummer van mei 1990 van dit blad citeert W. Veldman hieromtrent uit het Besluit Taak Departementale Accountantsdiensten: "Dit oordeel, waarmee de accountantsdienst de algemene controle afiondt, wordt gegeven in de vorm van een verklaring van getrouwheid omtrent de verantwoording. Deze interne verklaring (die hoort bij een interne verantwoording) heeft, behalve op de getrouw'e weergave van de werkelijkheid, mede betrekking op de rechtmatigheid van de in de verantwoording opgenomen uitgaven en ontvangsten." Dit lijkt ook rechtmatigheid op detailniveau te omvatten, met name doordat uitgaven en ontvangsten worden genoemd.

Het is dus niet verwonderlijk dat Ten Wolde stelt: "In het geval dat op materiële schaal onrechtmatige uitgaven zijn gedaan, komt de accountant tot een negatief oordeel - er is niet voldaan aan de eis van rechtmatigheid - en maakt hij hiervan melding in zijn verklaring. Als de verantwoording niet aangeeft hoeveel en waarom onrechtmatig is uitgekeerd, is bovendien niet voldaan aan de eis van waarheidsgetrouw'heid."

Voor overheidsinstellingen zou ik mij hiermee wel kunnen verenigen. Maar dan vervolgt Ten Wolde: "Accountants die 'getrouwheid" niet ruim interpreteren, maar slechts denken aan de w'eergave (het beeld), zullen redeneren dat mits van de onrechtmatige uitgaven in de verantwoording melding wordt gemaakt de accountant een goedkeurende verklaring kan geven. Deze gedachtegang is mijns inziens onjuist: het beeld is weliswaar juist, maar de onrechtmatigheid van de uitgaven wordt daarmee niet opgeheven".

Maar: welke verklaring geeft de accountant in een dergelijk geval? Een afkeurende verklaring? Blijkens art. 13 lid 5 GBR houdt die in dat de verantwoording niet aan de eraan te stellen eisen voldoet, in casu dat "het beeld niet juist is", maar het beeld is kennelijk wél juist. Een afkeurende verklaring kan Ten Wolde dus niet bedoeld hebben, want dan zou hij aanzetten tot valsheid in geschrift.

Maar wat dan wél? Ten Wolde verzuimt dit aan te geven, en ook in de Richtlijnen voor de Accountantscontrole zijn geen aanwijzingen voor de te volgen gedragslijn te vinden. De enige mogelijkheid die ik uit vorenstaand citaat van Ten 
Wolde kan afleiden is: met de verantwoording wachten tot de onrechtmatigheid van de uitgaven is opgeheven.

Voor de goede orde: voor rechtmatigheid op totaalniveau is dit in de praktijk geen probleem. Indien is vastgesteld dat uitgaven de begroting hebben overschreden, dan wordt vóór de presentatie van de (jaar)rekening een suppletoire begroting bij de volksvertegenwoordiging ingediend. Ik heb meegemaakt dat deze nauwelijks toelichtingen op de overschrijdingen bevatte, en dat deze door de volksvertegenwoordigers ook niet werden gevraagd. De suppletoire begroting werd als hamerstuk aanvaard, en de rekening toonde nadien dat alle uitgaven net binnen de bijgestelde begroting waren gebleven. Klaar is Kees, althans de overheidsaccountant.

Het probleem schuilt in de rechtmatigheid op detailniveau. de opheffing van de onrechtmatigheid van afzonderlijke uitgaven en ontvangsten. Dit is menigmaal in feite onmogelijk. In de vergadering van 7 februari 1991 van de bijzondere Kamercommissie voor de ISMO-problematiek heeft de toenmalige staatssecretaris van Sociale Zaken en Werkgelegenheid in herinnering gebracht dat de onrechtmatige uitgaven uit hoofde van sociale verzekeringen werden geschat op $f 3$ miljard; de ten onrechte niet ontvangen premies werden op eenzelfde bedrag getaxeerd. Tezamen kwam dit uit op 1,5\% van het nationaal inkomen (Tweede Kamer, vergaderjaar 1990-1991, 17050, nr. 124).

Terzijde: het is maar goed dat de bepalingen omtrent de beëindiging van de opdracht in de zgn. 'frauderichtlijn' (Richtlijn voor de Accountantscontrole 3.03) van het NIVRA sedert de wijziging van januari 1995 niet meer van toepassing zijn op overheidsaccountants: anders zou, gegeven de daarin gehanteerde definitie van 'fraude', menige departementale accountantsdienst zonder voldoende gekwalificeerd personeel moeten werken.

P.K. van Boven stelt in een artikel in NIVRAgeschrift 52 (Rechtmatigheidscontrole en accountantscontrole bij de overheid; Kluwer, 1989) dat de rechtmatigheidseis bij een groep. een massa uitgaven veeleer betrekking behoort te hebben op de groep als geheel dan op individuele uitgaven.
Daardoor zouden elementen als tolerantie, misbruik en oneigenlijk gebruik, onduidelijke wetgeving en de status van beleidsregels aan de orde kunnen komen (blz. 49-50).

Bij de rechtmatigheidscontrole lijkt mij de introductie van een tolerantie zinvol: die wordt door het parlement kennelijk ook aanvaard bij de grenscontroles van personen en goederen. Regelmatig valt zelfs te lezen dat naar schatting slechts 10 a $15 \%$ van de import van verboden bewustzijnsverruimende middelen wordt onderschept. zonder dat deze publicaties tot politiek rumoer leiden, behoudens indien de politie blijkt mee te werken aan de verlaging van dit percentage. De introductie van een tolerantie, die in de praktijk vermoedelijk al lang wordt toegepast, biedt echter geen oplossing voor het conceptuele probleem: de vermenging van de rechtmatigheid van het handelen met de getrouwheid van de weergave. De andere door $V$ an Boven genoemde elementen leiden slechts tot verwatering van het begrip rechtmatigheid. Dat is misschien een aantrekkelijke oplossing voor ambtenaren en voor regeringspartijen, maar niet voor de gemeenschap als geheel.

Ik vermag op dit moment de vermeende onjuistheid van de opvatting van accountants die 'getrouwheid' eng interpreteren niet in te zien: als het parlement een departementale jaarrekening krijgt voorgelegd waarin (met een tolerantie) is aangegeven hoeveel onrechtmatig is uitgekeerd en die is voorzien van een goedkeurende accountantsverklaring, kan het zijn taak perfect uitoefenen: het kan de desbetreffende minister ter verantwoording roepen en deze dwingen (meer) maatregelen te nemen. Als de departementale jaarrekening niet aangeeft hoeveel ten onrechte is uitgekeerd, moet de accountant een afkeurende verklaring geven, echter niet omdat uitgaven onrechtmatig zijn gedaan, maar omdat niet in de verantwoording is vermeld dat zij onrechtmatig zijn gedaan. Ook dan is de volksvertegenwoordiging nog steeds in staat zijn taak naar behoren te vervullen.

Het Interdepartementaal Overleg van Departementale Accountantsdiensten (IODAD) heeft de volgende oplossing gekozen. In de accountantsverklaring bij een departementale verantwoording wordt eerst weergegeven aan welke eisen de verantwoording moet voldoen; de rechtmatigheidseis wordt daarin uitgedrukt als volgt: "dat de in de verantwoording opgenomen verplichtingen, 
uitgaven en ontrangsten tot stand zijn gekomen in olereenstemming net de begrotingswetten e'n met andere van toepassing zijnde wettelijke regelingen (zie ook P.S. van Nes en P.J.M. Kop, De Accountant, januari 1996).

Dit lijkt de rechtmatigheid op beide niveaus te omvatten. Voorts wordt aangegeven dat bij twijfel aan of geconslateerde gebreken in de rechtmatigheid op detailniveau beperkingen in het oordeel over de verant woording kunnen worden weergegeven: uiteraard zijn ook afkeuringen c.y. oordeelonthoudingen mogelijk.

Inhoudelijk zou de volksvertegenwoordiging met bovenvermelde oplossing uit de voeten moeten kunnen: de relevante feiten worden medegedeeld. Toch worden de oordelen over de verantwoordingen om de verkeerde reden gegeven: rechtmatigheid is geen eis aan de verantwoording, maar aan het handelen, hetgeen ook duidelijk uil het laatstgegeven citaat blijkt. Dit is in wezen heel gemakkelijk oplosbaar, namelijk door naast het oordeel over de getrouwheid van de verantwoording een afzonderlijk oordeel over de rechtmatigheid van uitgaven, ontvangsten en verplichtingen op te nemen.

Dat het ineenschuiven van rechtmatigheid en getrouwheid aanleiding tot gewrongen oplossingen kan geven, blijkt naar mijn mening ook uit een artikel van W. van der Zanden in NIVRA-geschrift 52 (1989). Daarin stelt hij voor om onzekerheden in de controle en onrechtmatigheden op te heffen via indemniteitswetten, walarin de Algemene Rekenkamer kan worden opgedragen de desbetreffende uitgaven in de rijksrekening te aanvaarden. In de Memorie van Toelichting bij zo'n indemniteitswet dient de desbetreffende minister dan aan te geven welke maatregelen hij inmiddels ter zake heeft genomen; het parlement kan daarover dan oordelen bij de behandeling van een dergelijk wetsontwerp. Wetstechnisch zal dit wel mogelijk zijn, maar een dergelijke opdracht aan de Algemene Rekenkamer, een Hoog College van Staat, is natuurlijk inhoudelijk onzindelijk: dit college zou formeel een situatie moeten alanvaarden ter bestrijding waarvan het in het leven is geroepen.

De kerm van het probleem schuilt in de kronkelige semantiek die ter zake in de wetgeving is verankerd: het beheer wordt goed- of afgekeurd door goed- of afkeuring van de verantwoording, de weergave van de consequenties van het beheer. Dit geldt overigens zowel binnen als buiten de overheid, getuige de verwarring die pleegt te ontstaan als aandeelhouders de jaarrekening van een onderneming atkeuren. Deze anomalie is oplosbaar, maar niet door accountants alléén: dit raakt de grondslagen van de mijns inziens anachronistische wetgeving. Maar er lijkt mij geen reden deze semantische kronkel buiten de overheid breder te hanteren dan thans gebruikelijk.

\section{De rol van de rechtmatigheid buiten de overheid}

Buiten de overheid ligt de problematiek anders. In de eerste plaats kent een huishouding buiten de overheid geen equivalent van 'wetten' die de 'rechtmatigheid' van uitgaven en ontvangsten regelen. Natuurlijk kennen die huishoudingen wel regels van interne controle, maar die hebben niet hetzelfde karakter: die regels worden door de verantwoordingsplichtige directic zelf gesteld, en deze kan er ook van afwijken. c.q. afwijkingen zelfstandig goedkeuren. soms in overleg met een toezichthoudend orgaan. Dit kan uitzondering lijden indien de instelling geheel of ten dele door de overheid wordt gesubsidieerd. maar dan staat de instelling eigenlijk geheel of ten dele binnen de overheid. Uiteraard zijn instellingen buiten de overheid ook onderworpen aan de door de overheid uitgevaardigde wetten, maar deze regelen niet de "rechtmatigheid" van de uitgaven en ontvangsten (door geboden). doch stellen daaraan in voorkomend geval grenzen (door verboden: steekpenningen aan ambtenaren) of voorwaarden (door voorwaardelijke geboden: facturen i.v.m. BTW).

Van eminent belang in dit verband is, dat in een rechtsstaat niemand is gehouden tot zelfbeschuldiging: de verplichting tot vermelding in de verantwoording van onrechtmatig handelen zou strijdig zijn met dit algemene rechtsbeginsel.

Tot dusverre volgt, zoals Ten Wolde ook stelt. de accountant die een belangrijke overtreding van een voorschrift constateert, de volgende twee gedragslijnen:

I hij meldt de overtreding aan directie en/of toezichthoudend orgaan, met de dringende aanbeveling tot redres;

2 hij stelt vast dat de (mogelijke) financiële gevolgen van de overtreding, met inachtneming van de door de directie genomen maatregelen tot redres, correct in de verantwoording zijn verwerkt of vermeld. 
Alleen de bevindingen ad 2. beïnvloeden zijn verklaring; onbevredigende reacties op de ad 1 . genoemde melding leiden uiteindelijk tot teruggave van de opdracht. Dit alles is - meer genuanceerd - geregeld in eerdergenoemde "frauderichtlijn' van het NIVRA (thans RAC 240).

Dit is ook de beste oplossing: rechtmatigheid wordt onderscheiden van getrouwheid, waardoor duidelijkheid ontstaat. Dat de eventuele teruggave van de opdracht niet geschikt is voor overheidsaccountants, en daarvoor ook niet is voorgeschreven. hangt samen met hun speciale positie in het maatschappelijk bestel.

Desondanks schuift het NIVRA ook in de nieuwe versie van de Richtlijnen voor de Accountantscontrole de rechtmatigheid onder de getrouwheid. Een dergelijk conceptueel gebrek in een basisdocument kan het beroep later onverwacht parten gaan spelen, met name indien vanuit het maatschappelijk verkeer de roep zou ontstaan de rechtmatigheidseis ook bij ondernemingen ten volle als onderdeel van de getrouwheidseis te beschouwen. Op een kwade dag kan gezegd worden dat het beroep zich deze eis al lang zelf stelt.

\section{Conclusie}

Rechtmatigheid heeft betrekking op het handelen, getrouwheid op de weergave van deszelfs gevolgen. Het ineenschuiven van die twee begrippen is conceptueel onzindelijk en leidt tot onduidelijke, zoal niet onmogelijke oplossingen. In concreto: de rechtmatigheid dient uit $\S 200.7 \mathrm{~A}$ van de Richtlijnen voor de Accountantscontrole te worden geschrapt. 